\title{
EFEK PENAMBAHAN SUSPENSI NANOKITOSAN PADA EDIBLE COATING TERHADAP AKTIVITAS ANTIBAKTERI
}

\author{
Emma Rochima $^{{ }^{*}}$, Elisah Fiyanih ${ }^{1}$, Eddy Afrianto ${ }^{1}$, I Made Joni ${ }^{2}$, \\ Ujang Subhan ${ }^{2}$, Camellia Panatarani ${ }^{2}$
}

\author{
${ }^{1}$ Program Studi Perikanan, Fakultas Perikanan dan Ilmu Kelautan, Universitas Padjadjaran \\ ${ }^{2}$ Pusat Penelitian Teknologi Nano dan Grafen Universitas Padjadjaran \\ Jalan Raya Bandung-Sumedang Km. 21 Jatinangor, UBR 46000 Telepon (022) 87701519 \\ Korespondensi: emma.rochima@unpad.ac.id \\ Diterima: 20 November 2017 / Disetujui: 17 April 2018
}

Cara sitasi: Rochima E, Fiyanih E, Afrianto E, Joni IM, Subhan U, Pranatarani C. 2018. Efek penambahan suspensi pada edible coating terhadap aktivitas antibakteri. Jurnal Pengolahan Hasil Perikanan Indonesia. 21(1): 127-136.

\begin{abstract}
Abstrak
Edible coating atau edible film didefinisikan sebagai lapisan tipis yang dapat dikonsumsi dan berfungsi melindungi makanan dari kerusakan akibat kelembaban, oksigen, dan perpindahan zat terlarut. Komponen penyusun edible coating dapat dibedakan menjadi tiga jenis yaitu hidrokoloid, lipid dan komposit. Penelitian ini bertujuan untuk mendapatkan edible coating berbasis karaginan-pati termodifikasi dengan penambahan suspensi nanokitosan hasil proses beads-milling sebagai bahan antibakteri dan aplikasinya pada buah strowberi. Suspensi edible dibuat dengan mengkombinasikan karaginan jenis kappa dengan pati termodifikasi dan penambahan larutan nanokitosan sebesar $0,5 \%, 1 \%, 1,5 \%$, dan $2 \%$ (v/v). Pengujian antibakteri dilakukan dengan metode zona hambat dan efek dari penggunaan edible coating ditentukan melalui susut bobot buah strowberi. Karakteristik edible coating yaitu ketebalan dan tingkat transparansi diukur dengan cara mencetak edible pada plat plastik sehingga membentuk film. Penambahan suspensi nanokitosan $1 \% \mathrm{v} / \mathrm{v}$ pada larutan edible cukup efektif menghambat pertumbuhan Escherichia coli dan Staphylococcus aureus, hal ini terbukti setelah satu minggu, susut bobot buah strowberi yang dipapar dengan E. coli $6,13 \%$ lebih kecil jika dibandingkan dengan S. aureus sebesar 6,26\%. Suspensi edible memiliki ketebalan 0,065 mm dengan tingkat transparansi sebesar 82,56. sesuai standar Chroma Meter.
\end{abstract}

Kata kunci: karaginan, ketebalan, komposit, pati, transparansi

\section{The Effect of Nanochitosan Suspension Addition Produced by Beads Milling Method in Edible Coating on Antibacterial Activity}

\begin{abstract}
Edible coating or edible film is defined as thin film that can be consumed and provide protection against moisture, oxygen, and dissolved substances in food. Components of edible coating can be divided into three types: hydrocolloids, lipids, and composites. The aim of this research was to produce the edible coating based on starch-carrageenan modification with nanochitosan suspension addition of beads-milling production as antibacteria agent and its application on strawberry fruit. Edible solution produced by kappacarrageenan with starch modification combination and the addition of nanochitosan of $0.5 \%, 1 \%, 1.5 \%$, dan $2 \%(\mathrm{v} / \mathrm{v})$. Antibacteria assessment was carried out by resistance-zone method from edible coating determined by lost of weight of strawberry fruit. Edible characteristic of thickness and transparancy level measured by the way of copying this edible on the plastic plat to form the film. The result of this research concluded that the addition of nanochitosan suspension of $1 \%(\mathrm{v} / \mathrm{v})$ in the edible was quite effective for inhibiting Escherichia coli and Staphylococcus aureus growth via different mechanism The decrease in shrinkage of strawbery fruit weight exposed to E. coli (6.13\%) was lower than shrinkage exposed by S.aureus $(6.26 \%)$ after 1 week. The edible suspension had the thickness of $0.059 \mathrm{~mm}$ and the transparancy level of 87.88 showed the same as standard of Chroma Metre.
\end{abstract}

Keywords: carrageenan, starch, thickness, transparancy 


\section{PENDAHULUAN}

Kesadaran masyarakat yang semakin tinggi akan pentingnya konsumsi makanan yang sehat dan aman, serta kepedulian terhadap lingkungan, membuka peluang bagi penerapan teknologi pengawetan pangan, antara lain melalui pengemasan dengan edible coating (Winarti et al. 2011). Karaginan dan pati merupakan biopolimer alam yang sangat potensial sebagai bahan baku pembuatan edible coating, keduanya merupakan polisakarida yang tersedia melimpah di alam, bersifat mudah terurai (bio-degradable), mudah diperoleh dan murah. Kelebihan karaginan sebagai edible film yaitu dapat membentuk gel yang baik, elastis, dapat dimakan, dan dapat diperbaharui, sedangkan karaginankelemahan yaitu kemampuan sebagai barrier terhadap transfer uap air yang rendah, sehingga membatasi pemanfaatannya sebagai bahan kemasan (Handito 2011).

Sifat-sifat pati juga sesuai untuk bahan edible coating atau film karena dapat membentuk film yang cukup kuat. Edible film berbasis pati mempunyai kelemahan yaitu resistensinya terhadap air rendah dan sifat permeabilitasnya terhadapuap air juga rendah karena sifat hidrofilik pati dapat mempengaruhi stabilitas dan sifat mekanisnya (Garcia et al. 2011). Bunga et al. (2017) melaporkan bahwa edible film menggunakan pati komersil dan pati B. gymnorrhiza dari Halmahera Utara, perlakuan terbaik terdapat pada edible film dengan pati $4 \%$, karaginan $0,6 \%$ dan pektin $0,5 \%$, sedangkan Rusli et al. 2017 melaporkan bahwa edible film karaginan 3\% dan pemlastis gliserol $10 \%$ menghasilkan edible film dengan karakteristik terbaik. Peningkatan karakteristik fisik maupun fungsional dari film berbasis karaginan-pati, dapat dilakukan dengan penambahan biopolimer atau bahan lain, antara lain bahan yang bersifat hidrofobik dan yang memiliki sifat antimikroba, salah satu biopolimer hidrofobik (bahan tahan air) yang direkomendasikan untuk memperbaiki karakteristik film dari karaginan-pati sekaligus mempunyai aktivitas antimikroba adalah kitosan (Chillo et al. 2008).

Kitosan merupakan senyawa polimer yang dihasilkan dari ekstraksi hewan bercangkang keras (krustasea) dan biomaterial terbanyak setelah selulosa (Mincea et al. 2012). Sifat-sifat unik yang dimiliki kitosan telah mendorong berkembangnya penelitian yang menggunakan kitosan dan modifikasinya mencakup perubahan ukuran partikel yang mengarah pada orde nano (Suptijah et al. 2011). Kitosan telah banyak digunakan sebagai bahan pembuat biodegradable film dan pengawet pangan yang tahan terhadap mikroba. Sifat antibakteri kitosan berasal dari struktur polimer yang mempunyai gugus amin bermuatan positif, sedangkan polisakarida lain umumnya bermuatan negatif atau netral (Perinelly et al. 2018; Nouri et al. 2018; Vo dan Lee 2018). Gugus amin kitosan dapat berinteraksi dengan muatan negatif suatu molekul misalnya protein dari mikroba sehingga mampu memperpanjang masa simpan contohnya pada fillet daging ikan gabus (Wahyuni et al. 2013) dan buahbuahan antara lain pada pepaya dan apel (Tapia et al. 2007), melon (Massilia et al. 2008), apel (Rojas-Grau et al. 2008) dan strowberi atau sayuran wortel (Simoes et al. 2009). Modifikasi kitosan menjadi bentuk nano dimanfaatkan sebagai bahan tambahan filler pada formula edible sehingga akan menghasilkan nanokomposit untuk meningkatkan aktivitas antibakteri. Hal ini dikarenakan luas permukaan dan muatan positif dari gugus amin partikel nano kitosan yang besar (Xing et al. 2011).

Nanokitosan dapat disintesis dari berbagai metode. Penentuan metode yang digunakan tergantung faktor-faktor di antaranya ukuran partikel yang diinginkan, stabilitas kimia dan panas partikel, profil kinetik partikel dan toksisitas residu yang terkait dengan produk akhir (Agnihotri et al. 2004). Rochima et al. (2017) melaporkan bahwa nanokitosan dapat disintesis menggunakan metode beads-milling yang menghasilkan suspensi nanokitosan dengan ukuran partikel rata-rata $230 \mathrm{~nm}$. Suspensi nanokitosan tersebut sangat potensial untuk diaplikasikan sebagai filler sehingga akan meningkatkan sifat-sifat fungsional edible terutama aktivitas antibakteri. Penelitian mengenai efek 
penambahan suspensi nanokitosan hasil metode beads-milling perlu dilakukan terhadap aktivitas antibakteri edible coating berbasis karaginan-pati dan pengaruhnya pada susut bobot buah strowberi yang telah ter-coating. Tujuan penelitian ini untuk mendapatkan edible coating berbasis karaginan-pati termodifikasi dengan penambahan suspensi nanokitosan hasil proses beads-milling sebagai bahan antibakteri dan aplikasinya pada buah strowberi.

\section{BAHAN DAN METODE Bahan dan Alat}

Bahan yang digunakan dalam penelitian ini yaitu karaginan komersil jenis semirefined kappa, pati komersil termodifikasi, nanokitosan dari limbah cangkang rajungan sediaan Laboratorium Pengolahan Hasil Perikanan Fakultas Perikanan dan Ilmu Kelautan Unpad (Rochima et al. 2016). Suspensi nanokitosan dengan ukuran ratarata $500 \mathrm{~nm}$ hasil proses beads milling (Joni et al. 2013) dari Pusat Penelitian Teknologi Nano dan Graphene Unpad. Buah strowberi, asam asetat $1 \%$ (Merck), natrium asetat (Merck), etanol (Merck), akuades, gliserol (Merck), Nutrient Agar Merck, dan Nutrient Broth Merck. Alat yang digunakan yaitu alat-alat gelas (Pyrex), neraca digital OHAUS dengan ketelitian 0,0001 gram, hot plate stirrer (Sigma Aldrich), oven (Kirin Ltd), termometer.

\section{Metode Penelitian}

Metode penelitian yang digunakan dalam penelitian ini adalah metode eksperimental terdiri dari empat perlakuan, dengan variabel penambahan suspensi nanokitosan sebagai berikut:

$$
\begin{aligned}
\mathrm{A}= & \text { Konsentrasi suspensi nanokitosan } \\
& 0,5 \% \\
\mathrm{~B}= & \text { Konsentrasi suspensi nanokitosan } \\
& 1,0 \% \\
\mathrm{C}= & \text { Konsentrasi suspensi nanokitosan } \\
& 1,5 \% \\
\mathrm{D}= & \text { Konsentrasi suspensi nanokitosan } \\
& 2,0 \%
\end{aligned}
$$

Keterangan: (persentase terhadap volume larutan edible).

\section{Pembuatan nanokomposit edible coating}

Pembuatan larutan komposit mengacu pada Thakur et al. (2016) yang dimodifikasi. Pembuatan nanokomposit diawali dengan melarutkan tepung tapioka termodifikasi sebanyak 1 gram didalam $100 \mathrm{~mL}$ akuades. Larutan dipanaskan pada suhu $60^{\circ} \mathrm{C}$ sampai dengan $70^{\circ} \mathrm{C}$ serta diaduk di atas hot plate stirrer. Larutan yang sudah mengental ditambahkan 1,2 $\mathrm{mL}$ gliserol dan tetap dipanaskan serta diaduk sampai tergelatinisasi dan homogen. Larutan karaginan dibuat dengan cara karaginan melarutkan tepung karaginan sebanyak 1 gram di dalam $100 \mathrm{~mL}$ akuades, kemudian dipanaskan dan diaduk di atas hot plate stirrer pada suhu $90^{\circ} \mathrm{C}$ sampai dengan $100^{\circ} \mathrm{C}$.

Larutan pati termodifikasi dan larutan karaginan yang sudah tergelatinisasi dicampur ke dalam beaker glass dengan konsentrasi larutan pati termodifikasi sebanyak $75 \mathrm{ml}$ dan larutan karaginan sebanyak $25 \mathrm{~mL}$. Larutan karaginan-tapioka termodifikasi diaduk dan dipanaskan di atas hot plate stirrer selama 1 jam, pada suhu $65^{\circ} \mathrm{C}$, kemudian ditambahkan dengan suspensi nanokitosan $1 \%(\mathrm{v} / \mathrm{v})$ sedikit demi sedikit menggunakan pipet volume dengan tetap dipanaskan di atas hot plate stirrer sambil terus diaduk menggunakan pengaduk gelas. Larutan tersebut dimasukkan ke dalam botol semprot mini untuk keperluan aplikasi coating pada buah strowberi. Buah strowberi dilapisi larutan edible coating dengan cara disemprot di atas permukaan buah. Ketebalan dan tingkat transparansi edible, di ukur dengan cara dilakukan pencetakan edible pada plat plastik berukuran 20x20 cm menjadi film, kemudian dilakukan pengeringan pada suhu ruang selama 2 hari.

\section{Karakterisasi edible coating}

Aktivitas antibakteri larutan edible coating nanokitosan

Pengujian aktivitas antibakteri edible coating terhadap bakteri patogen dilakukan dengan metode zona hambat mengacu pada Rhim et al. (2006) yang dimodifikasi. Bakteri yang digunakan yaitu $S$. aureus dan E. coli. Zona penghambatan adalah lebar areal bening 
yang terbentuk di sekitar sumur yang diukur dengan jangka sorong dengan satuan $\mathrm{mm}$. Perhitungan zona hambat dilakukan dengan menggunakan persamaan sebagai berikut:

Zona hambat $=$ diameter kertas cakram - diameter zona bening

\section{Ketebalan edible film}

Ketebalan edible diukur berdasarkan metode McHugh dan Krochta (1994) dengan menggunakan mikrometer sekrup dengan ketelitian $0,001 \mathrm{~mm}$ pada edible yang sudah membentuk film pada 5 posisi yang berbeda. Hasil pengukuran kemudian di rata-ratakan dan dijadikan sebagai nilai utama.

\section{Transparansi edible film}

Transparansi edible film diukur menggunakan metode Al-Hassan dan Norziah (2012). Film yang sudah dicetak ditempatkan pada plat berwarna putih dan skala Hunter Lab color. Nilai transparansi dihasilkan dari persamaan berikut:

$$
\Delta \mathrm{E}=\left(\Delta \mathrm{L}^{2}+\Delta \mathrm{a}^{2}+\Delta \mathrm{b}^{2}\right) 0.5
$$

dengan $\Delta L=$ Lstandard - Lsample, $\Delta a=$ astandard - asample and $\Delta b=$ bstandard bsample. Nilai standar untuk plat putih adalah $L=97,51, a=5,35$ and $b=-3,37$.

\section{Susut bobot buah strowberi}

Pengukuran susut bobot buah strowberi yang telah di-coating mengacu pada Liviawaty et al. (2010) dilakukan menggunakan persamaan sebagai berikut:

Susut bobot $=\frac{\text { bobot awal }- \text { bobot akhir }}{\text { bobot awal }} \times 100 \%$

\section{HASIL DAN PEMBAHASAN \\ Aktivitas Antibakteri Edible Coating Nanokitosan}

Hasil pengukuran zona hambat tetrasiklin sebagai control positif dan edible coating terhadap bakteri E. coli dan S. aureus (Tabel 1). Hasil menunjukkan bahwa kontrol positif memiliki kemampuan yang besar dalam menghambat kedua bakteri patogen. Hal tersebut karena tetrasiklin merupakan antibiotik yang sering digunakan untuk mengendalikan dan mencegah penyakit mikroba (Gokulana et al. 2017).

Penambahan suspensi nanokitosan pada larutan edible dapat menghambat aktivitas kedua jenis bakteri. Peningkatan konsentrasi suspensi nanokitosan pada larutan edible, menghasilkan nilai zona hambat yang fluktuatif pada kedua bakteri. Hal tersebut diduga karena saat konsentrasi nanokitoan dinaikkan, terjadi aglomerasi di dalam larutan edible, sehingga kitosan tidak cukup kecil untuk terakumulasi pada membran bakteri dan menimbulkan kematian bakteri (Antoniou et al. 2015).

Penambahan suspensi nanokitosan menghasilkan aktivitas penghambatan yang lebih tinggi pada E. coli jika dibandingkan dengan $S$. aureus pada setiap perlakuan. Zheng et al. (2003) melaporkan bahwa penghambatan oleh nanokitosan pada bakteri S. aureus dengan cara membentuk membran polimer pada permukaan sel sehingga menghambat nutrisi masuk ke dalam sel, sedangkan penghambatan nanokitosan pada E. coli diduga melalui mekanisme masuknya zat ke dalam sel sehingga mengganggu metabolisme bakteri. Menurut Tsai dan Su (1999) bahwa kitosan

Tabel 1 Aktivitas antibakteri edible coating nanokitosan

(Table 1 Antibacterial activity edible coating nanokitosan)

\begin{tabular}{ccc}
\hline \multirow{2}{*}{ Konsentrasi/Concentration } & \multicolumn{2}{c}{ Diameter zona hambat/Formed inhibitory zone $(\mathrm{mm})$} \\
\cline { 2 - 3 } & E. coli $(\mathrm{Gram}-)$ & S. aureus $(\mathrm{Gram}+)$ \\
\hline Positive control (Tetrasiklin 10 ppm) & 25.33 & 16.83 \\
$0.5 \%$ & 10.32 & 6.81 \\
$1 \%$ & 14.28 & 9.83 \\
$1.5 \%$ & 11.15 & 7.67 \\
$2 \%$ & 9.03 & 7.12 \\
\hline
\end{tabular}


memiliki efek bakterisidal terhadap bakteri E.coli, dan menghambat pertumbuhan Listeria monocytogenes (Coma et al. 2002). Vasconez et al. (2009) menyatakan bahwa jumlah populasi mikroba pada ikan salmon yang di coating dengan larutan kitosan tepung tapioka $(1: 2 \mathrm{~b} / \mathrm{b})$ selama 10 hari dengan kondisi penyimpanan $7-8^{\circ} \mathrm{C}$ populasi mikroba jauh lebih menurun jika dibandingkan dengan coating menggunakan tepung tapioka saja.

\section{Susut Bobot Buah Strowberi}

Hasil pengukuran susut bobot buah strawberi yang telah diberi perlakuan (Tabel 2). Nilai susut bobot strowberi yang di-coating dengan nanokitosan $1 \%$ yaitu $1,01 \%$. Hasil ini tidak jauh berbeda dengan buah strowberi kontrol (0\%) dengan susut bobot $0,98 \%$. Hasil analisis statistik menunjukkan bahwa tidak ada perbedaan nyata antara kontrol dengan perlakuan namun pemilihan $1 \%$ nanokitosan terbaik karena mempertimbangkan karakteristik strowberi yang masih terlihat segar dan utuh setelah penyimpanan selama tujuh hari. Marlina (2014) yang menyatakan bahwa buah tanpa pelapisan kitosan menyebabkan kulit buah menjadi lebih tipis dibandingkan dengan buah yang diberi perlakuan.

Pelapisan buah strowberi dengan edible coating dan penambahan suspensi nanokitosan dapat dikatakan memiliki kemampuan untuk mempertahankan susut bobot pada buah. Hal ini karena nanokitosan memiliki sifat antimikroba yang dapat menghambat bakteri patogen dan mikroorganisme pembusuk, termasuk jamur, bakteri gram positif dan bakteri gram negatif
(Hafdani 2011). Nanokitosan juga memiliki kemampuan sebagai pelapis yang mampu menghambat laju respirasi dan transpirasi, sehingga laju respirasi buah strowberi yang dilapisi memiliki nilai susut bobot lebih kecil. Henriette (2010) menyatakan bahwa nanokitosan digunakan sebagai pelapis guna menghalangi oksigen masuk dengan baik dan sebagai pelapis yang dapat dimakan langsung, karena nanokitosan tidak berbahaya terhadap kesehatan.

Pemilihan konsentrasi terbaik nanokitosan $1 \%$ juga diperkuat dengan hasil uji organoleptik pada buah stroberi. Hasil pengamatan subyektif menunjukkan buah stroberi yang di-coating dengan nanokitosan $1 \%$ menunjukkan karakteristik masih segar setelah disimpan selama 7 hari. Hasil secara deskriptif disajikan pada Tabel 3.

Buah strowberi merupakan salah satu jenis buah-buahan yang mengalami aktivitas biologissetelahpemanenanyangmenghasilkan hilangnya air dan terjadi pertukaran gas berkelanjutan dengan lingkungan sekitarnya melalui proses respirasi dan transpirasi. Hal ini berkontribusi langsung terhadap penurunan kualitas dan daya simpan buah strowberi hal tersebut meupakan parameter kritis dari daya saing produk segar di pasaran, oleh karena itu salah satu teknis untuk mengurangi kehilangan air pada produk buah segar dengan cara aplikasi edible coating sesegera mungkin setelah pemanenan. Teknis coating selain berhasil mengurangi kehilangan air (water loss) juga meningkatkan sifat antibakteri dari buah yang di-coating. Hal ini sesuai dengan hasil penelitian Ncama et al. (2018) menyatakan bahwa pengembangan bahan

Tabel 2 Susut bobot buah stawberi

(Table 2 Strawberry weight loss)

\begin{tabular}{ccc}
\hline \multicolumn{3}{c}{ Calculation of the weight loss of strawberry fruit (grams/day) } \\
\hline Konsentrasi nanokitosan/ & $\begin{array}{c}\text { Berat raa-rata selama } 7 \text { hari masa simpan } \\
\text { Average weight in } 7 \text { days }(g)\end{array}$ & $\begin{array}{c}\text { Susut bobot } \\
\text { Weight loss (\%) }\end{array}$ \\
\hline $0.0 \%$ & $6.89 \pm 0.01$ & $0.98^{\mathrm{a}}$ \\
$0.5 \%$ & $6.98 \pm 0.01$ & $1.00^{\mathrm{a}}$ \\
$1.0 \%$ & $7.07 \pm 0.01$ & $1.01^{\mathrm{a}}$ \\
$1.5 \%$ & $6.78 \pm 0.01$ & $0.97^{\mathrm{a}}$ \\
$2.0 \%$ & $7.11 \pm 0.01$ & $1.02^{\mathrm{a}}$ \\
\hline
\end{tabular}


Tabel 3 Karakteristik orgenoleptik buah strowberi yang di-coating dengan nanokitosan berbagai konsentrasi

(Table 3 Organoleptic characteristics of strawberry fruit coated with nanocitoses of various concentrations)

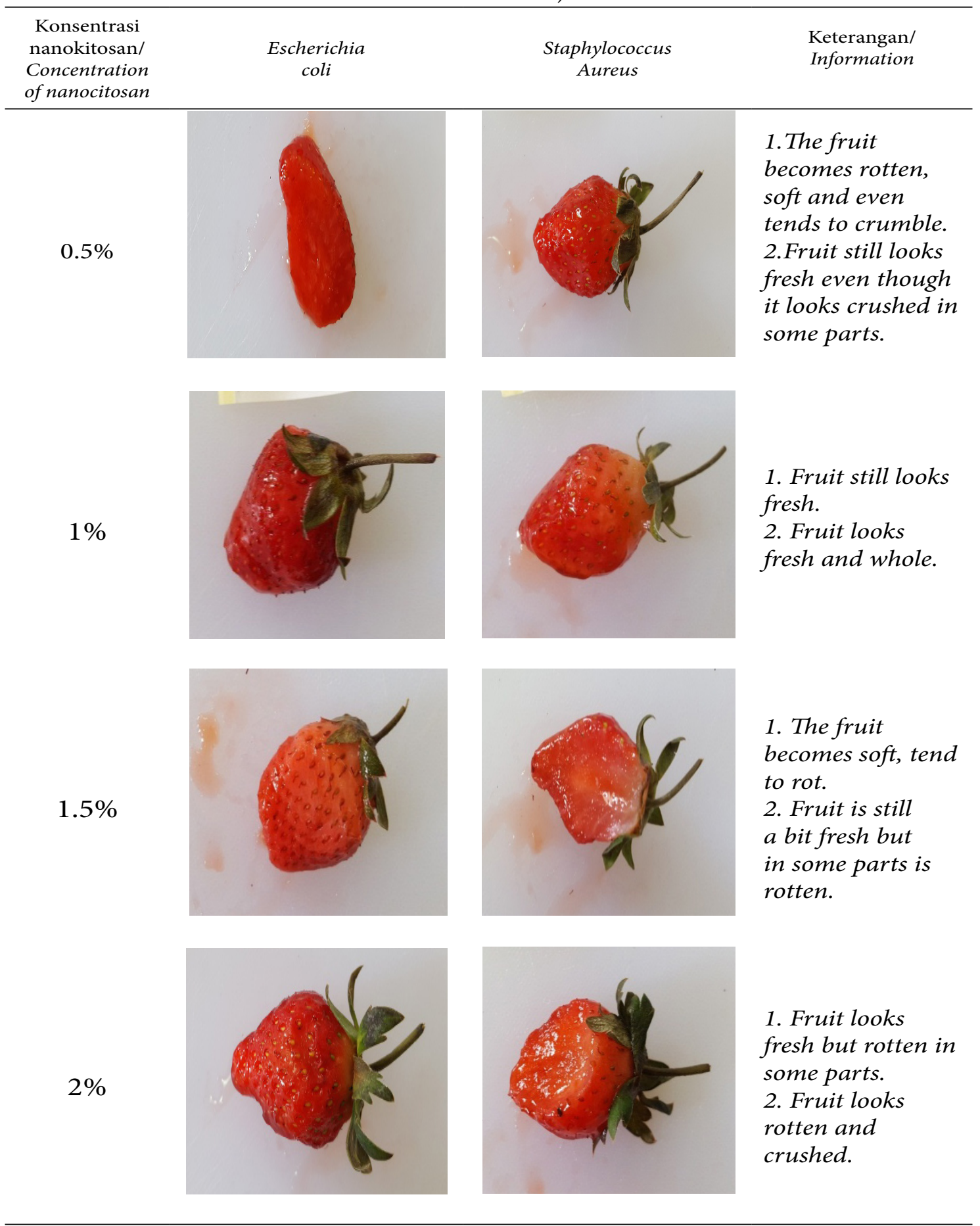

coating dari berbagai bahan alami seperti edible berfungsi untuk mempertahankan dan mengembangkan kualitas produk segar saat pemanenan menjadi trend terbaru saat ini.
Nanokitosan dalam penelitian ini digunakan sebagai bahan aktif antibakteri pada formulasi edible coating. Fungsi kitosan sebagai zat antibakteri pada edible coating 
dapat mencegah kontaminasi akibat aktivitas intrinsik alami dari buah stroberi. Secara organoleptik edible coating berfungsi sebagai carrier (pembawa) agen anti-browning (pencoklatan), zat nutrisi dan flavour (Shieks et al. 2013; Lin dan Zhao 2007). edible coating juga mampu menunda pematangan juga memperpanjang masasimpan (Gol et al. 2013; Rezaei dan Shabaszi 2018) dan dapat meningkatkan nilai estetika berupa kecerahan produk dan menekan kerusakan produk (Murmu dan Mishra 2018). Teknik edible coating merupakan teknik yang relatif murah untuk mempertahankan kualitas produk segar saat pemanenan (Shieks et al. 2013; Tiwari et al. 2016; Valencia-Chamorro et al. 2011).

\section{Karakteritistik Edible}

Hasil pengujian aktivitas antibakteri menunjukkan bahwa perlakuan terbaik adalah dengan penambahan suspensi nanokitosan $1 \%$. Berdasarkan hasil tersebut maka dilakukan karakterisasi berupa pengukuran ketebalan saat menjadi film dan tingkat transparansi. Hasil pengukuran ketebalan film ditampilkan pada. Larutan edible memiliki rerata ketebalan 0,065 $\pm 0,01 \mathrm{~mm}$, dan sesuai dengan standar ketebalan film yang telah dilaporkan (Japanese IndustrialStandard2012).Kombinasi jumlah akuades dan pemanasan menyebabkan granul karaginan-pati membentuk gelatinisasi yang baik dan selanjutnya granul-granul yang besar tidak mempengaruhi ketebalan edible (Averous et al. 2004).

Penambahan suspensi nanokitosan juga tidak mempengaruhi ketebalan karena konsentrasinya yang rendah. Penggunaan nanokitosan dengan konsentrasi rendah akan menghasilkan dispersi yang baik pada larutan edible. Penambahan gliserol sebagai plasticizer juga menurunkan kerapuhan film dengan menurunkan interaksi intra dan intermolekular ikatan hidrogen (Jimenez et al. 2012).

Tingkat transparansi edible dapat diindikasikan dengan nilai L-sample. Edible yang sudah dicetak memiliki nilai transparansi L-sample $82,56 \pm 1,12$. Nilai tersebut mengindikasikan bahwa film memiliki kenampakan transparan karena karaginan- pati sebagai bahan baku menghasilkan transparansi setelah dilarutkan. Penambahan gliserol dalam larutan edible dengan konsentrasi tertentu juga dapat menghasilkan larutan yang jernih (Farahnaky et al. 2013). Suspensi nanokitosan berkonsentrasi rendah juga memiliki kenampakan yang transparan (Rochima et al. 2017), sehingga tidak mempengaruhi kenampakan edible.

\section{KESIMPULAN}

Edible coating dari kombinasi kappa karaginan-pati dengan penambahan suspensi nanokitosan telah dibuat menggunakan metodepencampuran sederhana. Penambahan suspensi nanokitosan $1 \% \mathrm{v} / \mathrm{v}$ dari larutan edible efektif menghambat pertumbuhan E. coli dan S. aureus. Larutan edible memiliki ketebalan $(0,065 \mathrm{~mm})$ dan mempunyai tingkat transparansi 82.56 yang hampir sama dengan nilai standar pengukuran Chroma Meter.

\section{UCAPAN TERIMAKASIH}

Ucapan terimakasih disampaikan kepada Universitas Padjadjaran yang telah mendanai penelitian ini melalui Dana Hibah Riset Fundamental Unpad Tahun 2017 dengan No. Kontrak :855/UN6.3.1/PL/2017 Tanggal 8 Maret 2017.

\section{DAFTAR PUSTAKA}

Agnihotri SA, Mallikarjuna NN, Aminabhavi TM. 2004. Review on recent advances on chitosan based micro and nanoparticles in drug delivery. Journal of Controlled Release 100(1): 5-28.

Al-Hasan AA, Norziah MH. 2012. Starch gelatin edible films: water wapor permeability and mechanical properties as affected by plasticizers. Food Hydrocolloids. 26: 108-117.

Antoniou J, Liu F, Majeed H, Zhong F. 2015. Characterization of tara gum edible films incorporated with bulk chitosan and chitosan nanoparticles: a comparative study. Food Hydrocolloid. 44: 309-319.

Bunga SM, Jacoeb AM, Nurhayati T. 2017. Karakteristik pati dari buah lindur dan aplikasinya sebagai edible film. Jurnal Penelitian Perikanan Indonesia. 20(3): 446-455.

Chillo S, Flores S, Mastromatteo M, Conte A, 
Lý'a Gerschenson, dan del Nobile M A. 2008. Influence of glycerol and chitosan on tapioca starch-based edible film properties. Journal Food Engineering. 88: 159-168.

Farahnaky A, Saberi B dan Majzoobij M. 2013. Effect of glycerol on physical and mechanical properties of wheat starch edible films. Journal Texture Study. 44: 176-186.

Garcia N L, Ribbon AD, Aranguren M, Goyanes S. 2011. Effect of glycerol on the morphology of nanocomposites from thermoplastic starch and starch nanocrystals. Carbohydrate Polymers. 84(1): 203-210.

Gokulana K, Cernigliaa CE, Thomasa C, Pineirob SA, Khare S. 2017. Effects of residual levels of tetracycline on the barrier functions of human intestinal epithelial cells. Food Chemical Toxicology. 109: 253-263.

Gol NB, Patel PR, Rao TR. 2013. Improvement of quality and shelflife of strawberries with edible coating enriched with chitosan. Postharvest Biology and Technology 85: 185-195.

Hafdani FN, Sadeghinia N. 2011. A Review on application of chitosan as a natural antimicrobial. World Academy of Science. Engineering and Technology. 50.

Handito D. 2011. Pengaruh konsentrasi karaginan terhadap sifat fisik dan mekanik edible film. Jurnal Agroteksos. 21(2-3): 151-157.

Henriette MC, Azeredo, de Britto D. Assis OBG. 2010. Chitosan edible films and coating - review, Embrapa Tropical Agroindustry, Fortaleza, CE, Brazil. ISBN 978-1-61728-831-9.

Jimenez A, Fabra MJ, Talens P, Chiralt A. 2012. Effect of sodium caseinate on properties and ageing behaviour of corn starch based films. Food Hydrocolloid. 29: 265-271.

Joni IM, Panatarani C, Hidayat D, Setianto B. Wibawa M, Rianto A, Thamrin H. 2013. Synthesis and dispersion of nanoparticles, and Indonesian graphite processing. Padjadjaran International Physics Symposium. 20-26.
Krochta JM. 1994. Edible coating and film to improve food quality. Lancester (UK): Technomis Publisher. Co. Inc.

Lin D \& Zhao Y. 2007. Innovation in the development and application of edible coating for fresh and minimally processed fruit and vegetables. Comperehensive Reviews in Food Science and Food Safety. 6: 60-75.

Liviawaty E, Suhara O, dan Afrianto E. 2010. Buku Praktikum Teknologi Penanganan Hasil Perikanan. Bandung (ID): Unpad Press.

McHugh DJ. 1994. Production, properties and uses of alginate, In: D. J. McHugh (ed.) Production and Utilization of Products from Commercial Seaweeds. Rome (ITA): Food and Agriculture Organization of the United Nations.

Marlina L, Purwanto YA, Ahmad U. 2014. Aplikasi pelapisan kitosan dan lilin lebah untuk meningkatkan umur simpan salak pondoh. Jurnal Keteknikan Pertanian. 28 (1).

Mincea M, Negrulescu A, Ostafe V. 2012. Preparation, modification, and application of chitin nanowhisker: A Review. Reviews on Advanced Materials Science. 30: 225242.

Massilia RMR, Mosqueda MJ, Belloso OM. 2008. Edible alginate-based coating as carrier of antimicrobials to improve shelf-life and safety of fresh-cut melon. International Journal Food Microbiology. 121: 313-327.

Murmu SB, Mishra HN. 2018. The effect of edible coating based on Arabic gum, sodium caseinate and essensial oil of cinnamon and lemon grass on guava. Food Chemistry 245: 820-828.

Nouri A, Yaraki MT, Ghorbanpour M, Agarwal S, Gupta VK. 2018. Enhanced antibacterial effect of chitosan film using montmorillonite/ $\mathrm{CuO}$ nanocomposite. International Journal of Biological Macromolecules. 109: 1219-1231.

Ncama K, Magwaza LS, Mditshwa A, Tesfay SZ. 2018. Plant-based edible coating for managing postharvest quality of fresh horticultural produce: A review. Food 
Packaging and Shelf Life. 16: 157-167.

Perinelli DR, Fagioli L, Campana R, Jenny KW, Lam JKW, Baffone W, Palmieri GF, Casettari L, Bonacucina G. 2018. Chitosan-based nanosystems and their exploited antimicrobial activity. European Journal of Pharmaceutical Sciences. 117: 8-20.

Rezaei F, Shahbazi Y. 2018. Shelf life extention and quality attributes of sauced silver carp fillet: A comparison among direct addition, edible coating and biodegradable film. LWT-Food Science and Technology. 87: 122-133.

Rhim JW, Hong SI, Park HM, Perry KWNG. 2006. Preparation and characterization of chitosan-based nanocomposite films with antimicrobial activity. Journal of Agricultural and Food Chemistry. 54: 5814-5822.

Rojas-Grau MA, Tapia MS, Rodriguez FD, Carmona AJ, Belloso MO. 2007. Alginate and gellan based edible coatings as support of antibrowning agent applied on fresh cut Fuji apple. Food Hydrocolloids. 21: 118-127.

Rochima E, Azhary SY, Pratama RI, Panatarani C, Joni IM. 2017. Preparation and characterization of nanochitosan from crab shell waste by beads-milling method. International Conference On Food Science and Engineering 2016. IOP Conf. Proc. Series: Materials Science and Engineering.

Rochima E, Utami S, Hamdani H, Azhary SY, Praseptiangga D, Joni.IM, Panatarani C. 2017. The dispersion of fine chitosan particles by beads-milling. The 1 st International Conference and Exhibition on Powder Technology Indonesia (ICePTi) 2017. AIP Conf. Proc. 1927, 030032-1-030032-4.

Rusli A, Metusalach, Salengke, Tahir MM. 2017. Karakterisasi edible film karaginan dengan pemlastis gliserol. Jurnal Pengolahan Hasil Perikanan Indonesia. 20(2): 219-229.

Siekh RA, Malik MA, Al-Thabaiti SA, Shiekh MA. 2013. Chitosan as a novel edible coating for fresh fruit. Food Science and Technology Research. 19: 139-155.
Simoes ADN, Tudela JA, Allende A, Puschmann R, Gil MI. 2009. Edible containing chitosan and moderate modified atmospheres maintain quality and enhance phytochemicals of carrot stricks. Postharvest Biology and Technology. 51: 364-370.

Suptijah P, Jacoeb AM, Rachmania D. 2011. Karakterisasi nano kitosan cangkang udang Vannamei (Litopenaeus vannamei) dengan metode gelasi ionik. Jurnal Pengolahan Hasil Perikanan Indonesia. 14(2): 78-84.

Tapia MS, Rojas-Grau MA, Rodriguez FJ, Ramirez J, Carmona A, Belloso MO. 2007. Alginate- and gellan based edible films for probiotic coating on fresh cut fruits. Journal Food Science. 72(4): 190-196.

Thakur R, Saberi B, Pristijono P, Golding J, Stathopoulos C, Scarlett C, Bowyer M, Vuong Q. 2016. Characterization of rice ttarch-i-carrageenan biodegradable edible film, effect of stearic acid on the film properties. International Journal of Biological Macromolecules. 93: 952-960.

Tiwari A, Galanis A, Soucek MD. 2016. Biobased and environmentally benign coating. Material degradation and failures series. John Willey and Sons. 87-120.

Valencia C, Palou SA, del Rio MA, PerezGago MD. 2011. Antimocrobial edible film and coatings for fresh and minimally processed fruit and vegetables; A review. Critical Review in Food Science and Nutrition. 51: 872-900

Vo DT, Lee CK. 2018. Antimicrobial sponge prepared by hydrophobically modified chitosan for bacteria removal. Carbohydrate Polymers. (187):1-7.

Wahyuni S, Khaeruni A, Hartini. 2013. Kitosan cangkang Udang Windu sebagai pengawet fillet ikan Gabus (Channa striata). Jurnal Pengolahan Hasil Perikanan Indonesia. 16(3): 233-241.

Winarti C, Miskiyah, Widaningrum. 2012. Teknologi produksi dan aplikasi pengemas edible antimikroba berbasis pati. Jurnal Litbang Pertanian. 31(2): 8593.

Xing K, Chen XG, Liu CS, Cha DS, Park HJ. 2009. Oleoyl-chitosan nanoparticles 
inhibits EscherichiacoliandStaphylococcus aureus by damaging the cell membrane and putative binding to extracellular or intracellular targets. International Journal of Food Microbiology. 132(2): 127-133.

Zheng LY, Zhu JF. 2003. Study on antimicrobial activity of chitosan with different molecular weights. Carbohydrate Polymer. 54: 527-530. 